\title{
Digitalization as a Trend of Modern Development of the World Economy
}

\author{
NATALIIA BEZRUKOVA ${ }^{1}$, LARYSA HUK ${ }^{2}$, HANNA CHMIL ${ }^{3}$, LIUDMYLA VERBIVSKA ${ }^{4}$, \\ OLENA KOMCHATNYKH ${ }^{5}$, YEVHEN KOZLOVSKYI ${ }^{6}$ \\ ${ }^{1}$ Department of International Economic Relations and Tourism, National University "Yuri \\ Kondratyuk Poltava Politechnic, Poltava, UKRAINE, \\ ${ }^{2}$ Department of Social and Economic Problems of Labor, SO "Institute for Economics and \\ Forecasting, National Academy of Sciences of Ukraine", Kyiv, UKRAINE, \\ ${ }^{3}$ Department of Marketing and Commercial Activities, Kharkiv State University of Food Technology \\ and Trade, Kharkiv, UKRAINE, \\ ${ }^{4}$ Department of Business, Trade and Stock Exchange Operations, Yuriy Fedkovych Chernivtsi \\ National University, Chernivtsi, UKRAINE, \\ ${ }^{5}$ Department of Economics, National Transport University, Kyiv, UKRAINE, \\ ${ }^{6}$ Department of Hotel-Restaurant and Tourism Business, Kyiv National University of Culture and \\ Arts, Kyiv, UKRAINE
}

\begin{abstract}
Transformation of economies with the application of information and communication technologies not only strengthens the competitiveness of countries in the international market, but also helps optimize and improve business processes in the international business environment. The purpose of the academic paper is to study the impact of digitalization on the development of the world economy on the example of the economies of the European Union member states. The following methods have been used, namely: analysis, description, generalization, induction, deduction, tabular representation, graphical representation, correlation analysis, systematization and grouping. Results: The positions of the European Union member states that are actively implementing the Digital Single Market strategy have been analyzed. It has been established that according to The Digital Economy and Society Index (DESI), Finland, Sweden, Denmark, the Netherlands and Malta have been among the top 5 leaders with the highest level of digitalization of the economy in 2020. Based on the study of The IMD World Digital Competitiveness Ranking, it has been found that the European Union member states, which are among the top 10 leading countries, such as: Denmark, Sweden and the Netherlands, have a high level of ability and readiness to research and implement digital technologies in order to achieve economic transformation and business transformation. The results of the correlation analysis have revealed the interrelationship between the values of Digital single market - promoting e-commerce for individuals and Enterprises that have provided training to develop / upgrade ICT skills of their personnel (\%). It has been proved that Sweden, Malta and Estonia show a very high positive correlation, which indicates that these countries are actively implementing digital technologies in the development of economic processes.
\end{abstract}

Key-Words: - Digitalization, Information and Communication Technologies, Transformation, Digital Economy, European Union

Received: May 22, 2021. Revised: November 16, 2021. Accepted: December 14, 2021. Published: January 9, 2022.

\section{Introduction}

The world economy is developing under the influence of numerous factors, among which the decisive place is occupied by information and communication technologies. Digitalization of economies significantly increases the level of their competitiveness in the international market and fundamentally changes business processes in the international business environment. Digitalization also provokes the emergence of new risks, among which cybersecurity risks occupy a special place.

Practice shows that those countries that are actively developing and implementing information and communication technologies as well as investing in this process all available and potential resources are characterized by the economies growing at an increased pace. With regard to the micro level, digitalization also has a significant impact on the performance of economic entities and, 
thus, encourages them to carry out new types of business activities.

Nowadays, it is worth highlighting the member states of the European Union among the countries that have a positive experience of introducing innovative and information and communication technologies in the development of their own economies. In addition, it should be noted that it is the member states of the European Union that are actively implementing the strategy of the Digital Single Market. Herewith, the level of digitalization of the economy of some of them is quite high, which indicates that digitalization has a positive effect on the growth of their economies. Therefore, the relevance of the subject of the academic paper is to determine the impact of digitalization on the development of the world economy on the example of the European Union member states.

\section{Literature Review}

Investigating the development of the modern economy Mentsiev et al. consider it in the context of the impact of digitalization [1]. Kravchenko et. al. study digitalization as a key factor in the growth of the global economy [2]. The scholars note that the significant impact on the growth of digitalization of the country's economy is revealed in the availability of quality Internet access, availability and openness of information and high level of innovation and scientific and technological potential. Jovanovic et al. in their study investigate the impact of digitalization on the sustainability of economic development [3]. The scientists argue that support at the appropriate level of modern business takes place in the context of the transition from traditional business models to digital innovation models, forasmuch as only under such conditions the competitiveness of business increases.

Lee et al. reveal the interrelationship between digitalization and resources in the context of the impact on increasing competitive advantage in global markets, the auxiliary elements of which are as follows: 1) marketing and its intermediary role in the system of increasing competitive advantage; 2) innovations; 3) educational potential [4]. At the same time, digitalization, influencing international business, contributes to its internationalization. Bataev et al. (2020) investigate the digitalization of the global economy based on the results of assessing the level of efficiency of the implemented cyberphysical systems [5]. The scholars have found out that for the effective implementation of cyberphysical systems, first, it is necessary to assess their efficiency level through the use of the method of the total cost of ownership of a cyber-physical system, in the context of which the cost of the implementation of a cyber-physical system and the cost of its operation are estimated.

Lovergine et al. study the impact of digitalization on the development of the labor market and demonstrate the interrelationship of artificial intelligence, robotics, innovative digital technologies with employment [6]. Along with this, they outline objectives and identify the skills that potential representatives of the labor market should possess in order to work under the conditions of a digitalized economy. Raj-Reichert et al. also investigate the impact of digitalization on labor and the workforce, noting that digitalization helps create new human resource management strategies and transnational employment strategies [7].

By the way, Moşteanu et al. consider the development of a "green" economy in the context of the impact of digitalization on these processes [8]. At the same time, scientists state that digitalization significantly changes the direction of economic development, based on the production of environmentally friendly products.

Neamţu et al. investigate the impact of digitalization on the level of development of the business sector in the system of knowledge economy [9]. Along with this, Mikhailov et al. assess the level of digitalization of the national economy and the impact of knowledge on this process, forasmuch as they are transformed into factors of production, with a clear distinction between intellectual activity and entrepreneurship and labor one [10]. At another point, Bejinaru explores the impact of digitalization on the knowledge economy as well as on education. The scholar identifies a number of benefits of digitalization, including time savings, low human error, transparency [11].

Dornberger et al. study the features of digitalization and its impact on the functioning of various business models and business processes in the global economy [12]. In order to adapt to the conditions caused by digitalization, scientists identify a number of stages of digital transformation of the economy, in particular: the stage of primary information systems, the stage of emergence of applications for e-business, the stage of Web 2.0 revolution and the stage of artificial intelligence. Ilcus analyzes the impact of digitalization on business processes [13]. The scholar focuses special attention on digital transformation, forasmuch as this aspect of digitalization is a key element of the prospective development of the economy and allows reorienting business processes in such a way as to 
achieve a positive effect from their implementation in the future. Youssef et al. investigate the interrelationship between the digitalization of the economy and business intentions, provided that key factors in the formation and development of entrepreneurial intentions are the personal attitude of entrepreneurs to doing business and the nature of their behavior [14].

Shkarlet et al. consider the development of economic entities in the context of digitalization of the economy, forasmuch as it contributes to significant savings of financial resources of economic entities, increases the efficiency of their activities, increases employee productivity, strengthens communication with customers, optimizes working hours, promotes new markets sales [15]. Belyaeva et al. study the impact of digitalization on the development of small and medium enterprises in the context of Industry 4.0 influence [16]. Branca et al. investigate the impact of digitalization on industry on the example of the metallurgical complex under the conditions of development of Industry 4.0 [17]. Androniceanu et al. analyze the interrelationship between digitalization and the workforce in the context of the impact of Industry 4.0 [18]. The scholars argue that digitalization has an impact on increasing labor productivity as well as changing workforce skills.

Sidorenko et al. [19] note that the assessment of digitalization in the context of the impact on economic processes can be carried out through the analysis of the following indicators, namely: a) Subindex of the social component of the project; b) Sub-index of the economic efficiency of the project; c) Sub-index of innovation; d) Sub-index of company/project management culture assessment. In the course of the research, scientists note that currently medium and small businesses are poorly aware of the functioning of new business models that have been developed and are being developed under the influence of digitalization. Kotarba examines the indicators used to assess digitalization and notes the close interrelationship between digitalization and analytics and data management processes, forasmuch as the digitalization process should be based on the proper execution of digital processes with appropriate data [20].

Kwilinski et al. study the digitalization features of the economies of the European Union member states in the context of the impact on overcoming poverty and social inequality [21]. According to the results of the investigations conducted, scientists claim that a high level of digitalization has a positive effect on reducing poverty and social inequality.
At the same time, the issues of the impact of digitalization on the development of the world economy in terms of effectiveness and practical aspects of such impact remain insufficiently disclosed.

The purpose of the academic paper is to study the impact of digitalization on the development of the world economy on the example of the economies of the European Union member states.

\section{Materials and Methods of the Research}

In order to reveal the purpose outlined in the academic paper, the following general scientific and specific research methods have been used, namely: 1) the method of theoretical analysis, the method of description and the method of generalization - in order to present the theoretical and practical fundamentals of digitalization as a key trend in the development of the world economy; 2) method of induction and method of deduction - in order to identify the problem, its study and detailing; 3) method of tabular and graphical representation - in order to generalize the level of digitalization of economies and the level of digital competitiveness of the EU member states' economies; 4) systematization method and grouping method - in order to determine the nature of the interrelationship between important variables of the digitalization process as a key trend in the world economy.

The investigation has been conducted on the example of the European Union member states, forasmuch as these countries are actively implementing the strategy of the Digital Single Market.

The study of the impact of digitalization on the development of the world economy on the example of the economies of the European Union member states has been carried out on the basis of the method of correlation analysis in order to establish the interrelationship between important variables, namely:

variable $X$, which reflects the Digital single market - promoting e-commerce for individuals $(\%)$,

and variable $\mathrm{Y}$, which reflects the Enterprises that have provided training to develop / upgrade ICT skills of their personnel (\%). The assessment of interrelationship degree between the studied indicators has been carried out using the Chaddock's scale. 
The following indicators have been selected as the information base of the scientific research, namely:

1) The Digital Economy and Society Index (DESI) - a cumulative indicator that reflects the level of economic development of the European Union member states in the digital competitiveness system (The European Commission, 2017, 2020) $[22 ; 23]$.

2) The IMD World Digital Competitiveness Ranking, which measures the level of ability and readiness of countries around the world (the review presents an overview and analysis of 63 countries) to investigate and implement digital technologies towards achieving economic transformation and business transformation (IMD World Competitiveness Center, 2016, 2020.) [24; 25].

3) Digital single market - promoting e-commerce for individuals, \% (Eurostat, 2021) [26].

4) Enterprises that have provided training to develop/upgrade ICT skills of their personnel, (\%) (Eurostat, 2021) [26].

\section{Results}

Analysis of the dynamics of The Digital Economy and Society Index in the period 2016-2020 has shown that Finland occupies a leading position, forasmuch as the level of digitalization of its economy is the highest (Table 1). Following Finland, Sweden and Denmark have a high level of digitalization of the economy. During the analyzed period, the 4th place in the ranking is occupied by the Netherlands. Malta demonstrates tendentious annual growth in the level of digitalization of the economy, which in 2020 has moved to the 5 th place from the 13th in 2016. The growth of digitalization level of the economy in recent years has also been demonstrated by Ireland and Romania. However, Portugal's position in the ranking is gradually declining, and the level of digitalization of its economy is growing at a slower pace to compare with other EU member states. Bulgaria, Greece, Romania, Italy and Cyprus have the lowest levels of digitalization of the economy among the European Union member states.

Table 1. Ranking of European Union member states according to The Digital Economy and Society Index (DESI)

\begin{tabular}{|l|l|c|c|c|c|c|c|c|c|c|c|}
\hline \multirow{2}{*}{ № } & \multirow{2}{*}{ Countries } & \multicolumn{2}{|c|}{2016} & \multicolumn{2}{|c|}{2017} & \multicolumn{2}{c|}{2018} & \multicolumn{2}{c|}{2019} & \multicolumn{2}{c|}{2020} \\
\cline { 2 - 12 } & Rank & Grade & Rank & Grade & Rank & Grade & Rank & Grade & Rank & Grade \\
\hline 1 & Austria & 10 & 54,0 & 10 & 57,0 & 13 & 48,5 & 14 & 51,1 & 13 & 54,3 \\
\hline 2 & Belgium & 5 & 58,0 & 6 & 61,0 & 11 & 50,1 & 11 & 53,0 & 9 & 58,7 \\
\hline 3 & Bulgaria & 27 & 35,0 & 27 & 37,0 & 27 & 33,5 & 28 & 33,8 & 28 & 36,4 \\
\hline 4 & Croatia & 23 & 40,0 & 24 & 43,0 & 21 & 40,8 & 20 & 44,3 & 20 & 47,6 \\
\hline 5 & Cyprus & 21 & 42,0 & 22 & 45,0 & 23 & 39,4 & 24 & 41,5 & 24 & 44,0 \\
\hline \multirow{2}{*}{6} & TheCzech & 17 & 46,0 & 18 & 50,0 & 19 & 44,7 & 18 & 47,3 & 17 & 50,8 \\
& Republic & & & & & & & & & & \\
\hline 7 & Denmark & 1 & 67,0 & 1 & 71,0 & 3 & 62,5 & 3 & 66,0 & 3 & 69,1 \\
\hline 8 & Estonia & 9 & 55,0 & 9 & 58,0 & 5 & 55,7 & 5 & 58,3 & 7 & 61,1 \\
\hline 9 & Finland & 2 & 66,0 & 2 & 68,0 & 2 & 62,8 & 1 & 68,1 & 1 & 72,3 \\
\hline 10 & France & 16 & 48,0 & 16 & 51,0 & 17 & 45,7 & 16 & 49,8 & 15 & 52,2 \\
\hline 11 & Germany & 11 & 54,0 & 11 & 56,0 & 14 & 47,9 & 13 & 51,2 & 12 & 56,1 \\
\hline 12 & Greece & 26 & 35,0 & 26 & 38,0 & 28 & 32,3 & 27 & 35,1 & 27 & 37,3 \\
\hline 13 & Hungary & 20 & 43,0 & 21 & 46,0 & 22 & 40,0 & 22 & 42,3 & 21 & 47,5 \\
\hline 14 & Ireland & 8 & 55,0 & 8 & 59,0 & 8 & 53,1 & 6 & 58,0 & 6 & 61,8 \\
\hline 15 & Italy & 25 & 38,0 & 25 & 42,0 & 25 & 36,2 & 23 & 41,6 & 25 & 43,6 \\
\hline 16 & Latvia & 19 & 46,0 & 19 & 47,0 & 15 & 46,8 & 15 & 49,9 & 18 & 50,7 \\
\hline 17 & Lithuania & 12 & 53,0 & 13 & 55,0 & 12 & 49,4 & 12 & 51,8 & 14 & 53,9 \\
\hline 18 & Luxembourg & 7 & 57,0 & 5 & 61,0 & 9 & 52,4 & 9 & 54,5 & 10 & 57,9 \\
\hline 19 & Malta & 13 & 53,0 & 12 & 55,0 & 7 & 53,3 & 8 & 55,3 & 5 & 62,7 \\
\hline 20 & The & 4 & 64,0 & 4 & 67,0 & 4 & 60,8 & 4 & 63,6 & 4 & 67,7 \\
& Netherlands & & & & & & & & & & \\
\hline 21 & Poland & 24 & 40,0 & 23 & 43,0 & 24 & 37,7 & 25 & 40,7 & 23 & 45,0 \\
\hline 22 & Portugal & 14 & 51,0 & 15 & 53,0 & 18 & 44,8 & 19 & 47,0 & 19 & 49,6 \\
\hline 23 & Romania & 28 & 31,0 & 28 & 33,0 & 26 & 35,1 & 26 & 36,5 & 26 & 40,0 \\
\hline 24 & Slovakia & 22 & 41,0 & 20 & 46,0 & 20 & 41,9 & 21 & 42,9 & 22 & 45,2 \\
\hline
\end{tabular}




\begin{tabular}{|l|l|c|c|c|c|c|c|c|c|c|c|}
\hline 25 & Slovenia & 18 & 46,0 & 17 & 51,0 & 16 & 45,9 & 17 & 48,7 & 16 & 51,2 \\
\hline 26 & Spain & 15 & 51,0 & 14 & 54,0 & 10 & 50,2 & 10 & 53,6 & 11 & 57,5 \\
\hline 27 & Sweden & 3 & 65,0 & 3 & 67,0 & 1 & 64,0 & 2 & 67,5 & 2 & 69,7 \\
\hline 28 & $\begin{array}{l}\text { The United } \\
\text { Kingdom }\end{array}$ & 6 & 58,0 & 7 & 60,0 & 6 & 53,5 & 7 & 56,6 & 8 & 60,4 \\
\hline
\end{tabular}

${ }^{1}$ Considering that the United Kingdom is not a member of the European Union since February 1, 2020, however, it has been included in Table 1 because the input data have been collected in advance and this country has been taken into account in the calculation of the rating.

It should be noted that in addition to The Digital Economy and Society Index, the European Commission has also developed The International Digital Economy and Society Index (I-DESI), which is a cumulative indicator that reflects the level of economic development of the European Union member states and other 18 countries of the world in the system of digital competitiveness. The results of the analysis of The International Digital Economy and Society Index show that in addition to the above-mentioned member states of the European Union, a high level of digitalization of the economy is observed in the United States, Iceland, Norway, Switzerland, Australia, New Zealand, Canada, Japan and Korea. However, the level of digitalization of the economy in Turkey, Brazil and Mexico is growing slowly [23].
The study of The IMD World Digital Competitiveness Ranking proves that a high level of ability and willingness to investigate and implement digital technologies towards achieving economic transformation and business transformation is observed in the following member states of the European Union, which, by the way, are also among the top 10 leading countries (according to ranking of The IMD World Digital Competitiveness Ranking), namely: Denmark (which has risen from the 6th place in 2016 to the 3rd place in 2020), Sweden (which has risen from the 5th place in 2016 to the 4th place in 2020) and the Netherlands (which has risen from the 8th place in 2016 to the 7 th place in 2020) (see Fig. 1).

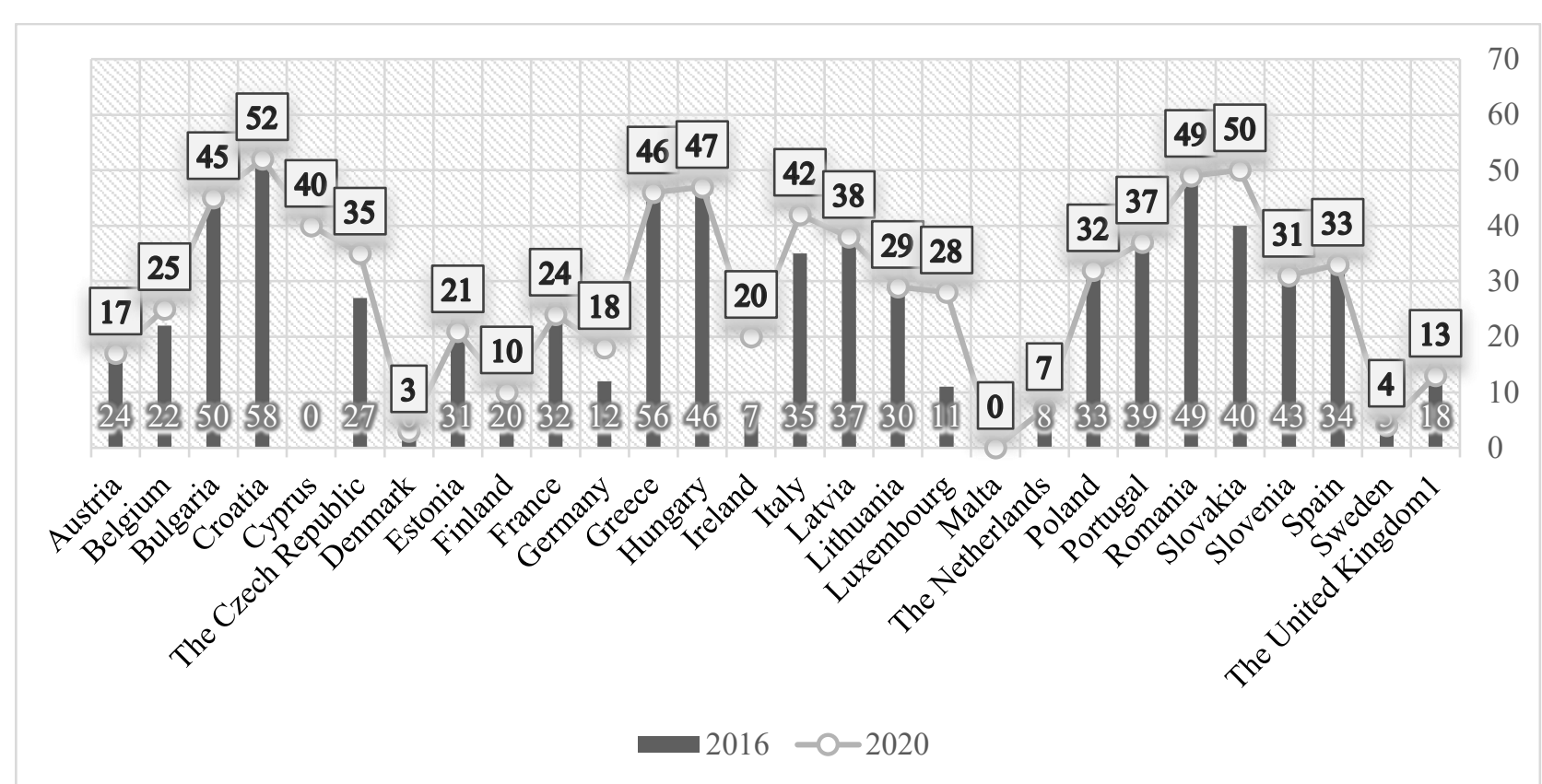

Fig. 1: Ranks of the European Union member states according to The IMD World Digital Competitiveness Ranking

In order to study the impact of digitalization on the development of the world economy on the example of the economies of the EU member states, a correlation analysis has been performed between the variable $\mathrm{X}$ - Digital single market - promoting e- commerce for individuals (\%) and the variable $\mathrm{Y}-$ Enterprises that have provided training to develop/upgrade ICT skills of their personnel (\%) (see Table 2). 
Table 2. Input data for correlation analysis

\begin{tabular}{|l|l|c|c|c|c|c|c|c|c|c|c|}
\hline \multirow{2}{*}{ № } & \multirow{2}{*}{ Countries } & \multicolumn{2}{|c|}{2016} & \multicolumn{2}{|c|}{2017} & \multicolumn{2}{|c|}{2018} & \multicolumn{2}{|c|}{2019} & \multicolumn{2}{|c|}{2020} \\
\cline { 2 - 12 } & $\mathrm{X}_{1}$ & $\mathrm{Y}_{1}$ & $\mathrm{X}_{2}$ & $\mathrm{Y}_{2}$ & $\mathrm{X}_{3}$ & $\mathrm{Y}_{3}$ & $\mathrm{X}_{4}$ & $\mathrm{Y}_{4}$ & $\mathrm{X}_{5}$ & $\mathrm{Y}_{5}$ \\
\hline 1 & Austria & 58 & 37 & 62 & 31 & 60 & 27 & 62 & 18 & 66 & 18 \\
\hline 2 & Belgium & 57 & 34 & 60 & 35 & 61 & 36 & 66 & 36 & 73 & 33 \\
\hline 3 & Bulgaria & 17 & 8 & 18 & 9 & 21 & 9 & 22 & 10 & 31 & 7 \\
\hline 4 & Croatia & 33 & 22 & 29 & 23 & 35 & 24 & 45 & 23 & 55 & 23 \\
\hline 5 & Cyprus & 29 & 22 & 32 & 26 & 32 & 26 & 39 & 31 & 47 & 25 \\
\hline \multirow{2}{*}{6} & TheCzech & 47 & 22 & 56 & 23 & 59 & 25 & 64 & 25 & 72 & 25 \\
& Republic & & & & & & & & & & \\
\hline 7 & Denmark & 82 & 28 & 80 & 27 & 84 & 28 & 84 & 31 & 89 & 30 \\
\hline 8 & Estonia & 56 & 13 & 58 & 13 & 61 & 13 & 68 & 17 & 68 & 17 \\
\hline 9 & Finland & 67 & 34 & 71 & 38 & 70 & 36 & 73 & 37 & 76 & 38 \\
\hline 10 & France & 66 & 20 & 67 & 19 & 67 & 19 & 70 & 21 & 70 & 15 \\
\hline 11 & Germany & 74 & 29 & 75 & 28 & 77 & 30 & 79 & 32 & 83 & 24 \\
\hline 12 & Greece & 31 & 15 & 32 & 12 & 36 & 14 & 39 & 15 & 46 & 12 \\
\hline 13 & Hungary & 39 & 16 & 39 & 17 & 41 & 17 & 49 & 16 & 60 & 16 \\
\hline 14 & Ireland & 59 & 30 & 53 & 30 & 59 & 30 & 67 & 31 & 74 & 27 \\
\hline 15 & Italy & 29 & 12 & 32 & 13 & 36 & 17 & 38 & 19 & 38 & 15 \\
\hline 16 & Latvia & 44 & 12 & 46 & 10 & 45 & 11 & 47 & 18 & 56 & 17 \\
\hline 17 & Lithuania & 33 & 10 & 38 & 11 & 43 & 9 & 48 & 11 & 54 & 14 \\
\hline 18 & Luxembourg & 78 & 29 & 80 & 28 & 72 & 27 & 72 & 27 & 79 & 21 \\
\hline 19 & Malta & 49 & 23 & 53 & 26 & 55 & 26 & 58 & 26 & 63 & 28 \\
\hline 20 & The & 74 & 22 & 79 & 24 & 80 & 26 & 81 & 26 & 87 & 24 \\
& Netherlands & & & & & & & & & & \\
\hline 21 & Poland & 42 & 12 & 45 & 12 & 48 & 13 & 54 & 13 & 61 & 18 \\
\hline 22 & Portugal & 31 & 23 & 34 & 21 & 37 & 19 & 39 & 28 & 45 & 23 \\
\hline 23 & Romania & 12 & 5 & 16 & 4 & 20 & 5 & 23 & 6 & 38 & 6 \\
\hline 24 & Slovakia & 56 & 20 & 59 & 17 & 59 & 18 & 60 & 18 & 62 & 16 \\
\hline 25 & Slovenia & 40 & 27 & 46 & 27 & 51 & 29 & 56 & 28 & 63 & 26 \\
\hline 26 & Spain & 44 & 23 & 50 & 23 & 53 & 21 & 58 & 22 & 63 & 20 \\
\hline 27 & Sweden & 76 & 25 & 81 & 28 & 78 & 24 & 82 & 32 & 84 & 32 \\
\hline
\end{tabular}

Source: Eurostat, 2021.

According to the results of the calculation, the corresponding values of the correlation coefficient have been obtained and the interrelationship between the dependent variables has been determined (using the Chaddock's scale to assess the degree of interrelationship) (see Table 3).

Table 3. The results of correlation analysis

\begin{tabular}{|c|c|c|}
\hline \multicolumn{2}{|c|}{ Countries } & Correlation coefficient \\
\hline \multicolumn{3}{|c|}{ Weak correlation } \\
\hline Luxembourg & \multirow{2}{*}{$\begin{array}{c}\text { Inverse } \\
\text { interrelationship }\end{array}$} & $-0,1926$ \\
\hline Slovenia & & $-0,1829$ \\
\hline Croatia & \multirow{2}{*}{$\begin{array}{c}\text { Direct } \\
\text { interrelationship }\end{array}$} & 0,0672 \\
\hline Portugal & & 0,2279 \\
\hline \multicolumn{3}{|c|}{ Moderate correlation } \\
\hline Germany & \multirow{4}{*}{$\begin{array}{l}\text { Inverse } \\
\text { interrelationship }\end{array}$} & $-0,4900$ \\
\hline Belgium & & $-0,3854$ \\
\hline France & & $-0,3516$ \\
\hline Greece & & $-0,3374$ \\
\hline Cyprus & \multirow{2}{*}{$\begin{array}{c}\text { Direct } \\
\text { interrelationship }\end{array}$} & 0,3401 \\
\hline The & & 0,4362 \\
\hline
\end{tabular}




\begin{tabular}{|c|c|c|}
\hline Netherlands & & \\
\hline \multicolumn{3}{|c|}{ Medium correlation (noticeable) } \\
\hline Ireland & \multirow{3}{*}{$\begin{array}{c}\text { Inverse } \\
\text { interrelationship }\end{array}$} & $-0,6091$ \\
\hline Hungary & & $-0,5652$ \\
\hline Bulgaria & & $-0,5303$ \\
\hline Latvia & \multirow{4}{*}{$\begin{array}{c}\text { Direct } \\
\text { interrelationship }\end{array}$} & 0,6277 \\
\hline Denmark & & 0,6728 \\
\hline Romania & & 0,6960 \\
\hline Lithuania & & 0,6983 \\
\hline \multicolumn{3}{|c|}{ High correlation } \\
\hline Spain & \multirow{2}{*}{$\begin{array}{c}\text { Inverse } \\
\text { interrelationship }\end{array}$} & $-0,8247$ \\
\hline Austria & & $-0,7890$ \\
\hline Finland & \multirow{4}{*}{$\begin{array}{l}\text { Direct } \\
\text { interrelationship }\end{array}$} & 0,8356 \\
\hline Italy & & 0,8434 \\
\hline $\begin{array}{l}\text { The Czech } \\
\text { Republic }\end{array}$ & & 0,8563 \\
\hline Poland & & 0,8932 \\
\hline \multicolumn{3}{|c|}{ Very high correlation } \\
\hline Slovakia & $\begin{array}{c}\text { Inverse } \\
\text { interrelationship }\end{array}$ & $-0,9174$ \\
\hline Sweden & \multirow{3}{*}{$\begin{array}{c}\text { Direct } \\
\text { interrelationship }\end{array}$} & 0,9099 \\
\hline Malta & & 0,9171 \\
\hline Estonia & & 0,9479 \\
\hline
\end{tabular}

The analysis of Table 3 makes it possible to note the presence of a direct very high interrelationship between Digital single market - promoting ecommerce for individuals (\%) and Enterprises that have provided training to develop / upgrade ICT skills of their personnel (\%) in Sweden, Malta and Estonia. In Slovakia, on the other hand, the interrelationship between the analyzed variables is also very high, but inverse, forasmuch as the growth of Digital single market - promoting e-commerce for individuals (\%) affects the reduction of Enterprises that have provided training to develop / upgrade ICT skills of their personnel (\%). In contrast to other EU member states, Luxembourg, Slovenia, Croatia and Portugal show a weak correlation between Digital single market promoting e-commerce for individuals (\%) and Enterprises that provided training to develop / upgrade ICT skills of their personnel (\%); moreover, the interrelationship between these variables in Luxembourg and Slovenia is inverse, and in Croatia and Portugal - direct.

\section{Discussion}

In the course of the research conducted, it has been established that there are currently numerous approaches to studying the impact of digitalization on the development of the world economy.
According to these approaches, it has been noted that the digitalization of the world economy is manifested through: 1) the growth of economies of countries that are quite active participants in the process of development and implementation of innovative and information and communication technologies $[1 ; 28]$; 2) high-quality Internet access, availability and openness of data, high innovation and scientific and technical potential $[2 ; 29] ; 3)$ the transition from traditional to digital innovative business models [3; 27]; 4) development of the knowledge system, forasmuch as knowledge is transformed into factors of production, while, at the same time, there is a clear separation of intellectual activity from entrepreneurial and labor one $[9 ; 10$; 11]; 5) intentions of entrepreneurship, forasmuch as the personal attitude of entrepreneurs to doing business and the nature of their behavior affects the effectiveness of the development and implementation of innovative new models of doing business $[14 ; 30]$; 6) development of Industry 4.0 $[16 ; 31]$.

It is worth agreeing with the conclusions of the studies carried out by scientists, however, it is advisable to note that one of the basic indicators for assessing the level of digitalization of the economy is The Digital Economy and Society Index (DESI), which has been developed by the European Commission. The Digital Economy and Society 
Index (DESI) is a cumulative indicator that is calculated as a weighted average of the following indicators, namely: 1) Connectivity; 2) Human Capital; 3) Use of Internet Services; 4) Integration of Digital Technology. According to the results of the calculation of the Digital Economy and Society Index (DESI) (which reflects the level of economic development of the European Union member states in the system of digital competitiveness), such member states of the European Union as: Finland, Sweden, Denmark, the Netherlands and Malta have a high level of digitalization of the economy in 2020. At the same time, the lowest levels of digitalization of the economy are observed in Bulgaria, Greece, Romania, Italy and Cyprus.

In a study of Sidorenko et al. it has been proposed to conduct an assessment of the digitalization of the economy through: 1) Sub-index of the social component of the project; 2) Sub-index of the economic efficiency of the project; 3) Subindex of innovation; 4) Sub-index of company/project management culture assessment [19].

Based on the above-mentioned, the investigation of the impact of digitalization on the development of the world economy has been conducted in the academic paper on the example of the EU member states, forasmuch as these countries are actively implementing the strategy of the Digital Single Market. Thus, according to the results of the correlation analysis conducted between the variable Digital single market - promoting e-commerce for individuals (\%) and the variable Enterprises that have provided training to develop / upgrade ICT skills of their personnel (\%), it has been established that Sweden, Malta and Estonia have a rather high level of digitalization of the economy. This is evidenced by the presence of a direct very high relationship between Digital single market promoting e-commerce for individuals (\%) and Enterprises that have provided training to develop / upgrade ICT skills of their personnel (\%). The data obtained as a result of the correlation analysis are to some extent identical to the results of the Digital Economy and Society Index (DESI).

\section{Conclusion}

It has been found that digitalization is a key factor in the growth of the global economy, and in order to study its impact on world economic growth, various approaches have been developed, according to which the level of digitalization of the countries' economies is assessed. One of the basic indicators for assessing the level of digitalization of the economy is The Digital Economy and Society Index (DESI) which summarizes indicators on Europe's digital performance and tracks the progress of EU countries.

It is advisable to conduct correlation analysis for determining the level of digitalization of the economy in countries that are actively implementing the strategy of the Single Digital Market by using the indicators of the Digital single market promoting e-commerce for individuals (\%) and Enterprises that have provided training to develop / upgrade ICT skills of their personnel (\%). The obtained results prove that Sweden, Malta and Estonia are countries with a high level of digitalization of the economy among the studied countries, as evidenced by the presence of a direct high correlation between the studied variables.

The practical significance of the obtained research results lies in the fact that the proposed approach to the application of correlation analysis between variables Digital single market - promoting e-commerce for individuals (\%) and Enterprises that have provided training to develop / upgrade ICT skills of their personnel (\%) is universal, forasmuch as the study of the digitalization level of the economy can be conducted on the example of any country in the world.

The future directions of the research area involve studying the level of digitalization of the world economy, based on a comprehensive study of the digitalization of the economy of each country.

\section{References:}

[1] Mentsiev, A. U., Engel, M. V., Tsamaev, A. M., Abubakarov, M. V., \& Yushaeva R. S.-E. The Concept of Digitalization and Its Impact on the Modern Economy. International Scientific Conference «Far East Con» (ISCFEC 2020). Advances in Economacs, Business and Management Research, 128, 2020. pp. 29602964.https://doi.org/10.2991/aebmr.k.200312.4 22

[2] Kravchenko, O., Leshchenko, M., Marushchak, D., Vdovychenko, Yu., \& Boguslavska, S. The digitalization as a global trend and growth factor of the modern economy. SHS Web of Conferences 65(1):07004. 2019. https://doi.org/10.1051/shsconf/20196507004

[3] Jovanović, M., Dlačić, J., \& Okanović, M. Digitalization and society's sustainable development - Measures and implications. Zbornik Radova Ekonomski Fakultet u Rijeka, 36(2), $2018 . \quad$ pp. 905-928. http://doi.org/10.18045/zbefri.2018.2.905 
[4] Lee, Ya. Yi., \& Falahat, M. The Impact of Digitalization and Resources on Gaining Competitive Advantage in International Markets: Mediating Role of Marketing, Innovation and Learning Capabilities. Technology Innovation Management Review, 9 (1), 2019. pp. 26-38.

[5] Bataev, A. V., \& Aleksandrova A. Digitalization of the World Economy: Performance Evaluation of Introducing CyberPhysical Systems. 2020 9th International Conference on Industrial Technology and Management (ICITM). https://doi.org/10.1109/ICITM48982.2020.908 0378

[6] Lovergine, S., \& Pellero, A. This Time it Might be Different: Analysis of the Impact of Digitalization on the Labour Market. European Scientific Journal, 14 (36), 2018. pp. 68-81. http://dx.doi.org/10.19044/esj.2018.v14n36p68

[7] Raj-Reichert, G., Zajak, S., \& Helmerich, N. Introduction to special issue on digitalization, labour and global production. Competition \& Change, 25(2), 2021. pp.133-141. https://doi.org/10.1177/1024529420914478

[8] Moşteanu, N. R., \& Faccia, A. Digitalization and Green Economy - changes of business perspectives. ICCBDC '20: Proceedings of the 2020 4th International Conference on Cloud and Big Data Computin, 2020. pp. 108-112. https://doi.org/10.1145/3416921.3416929

[9] Neamţu, D. M., Hapenciuc, C.-V. \& Bejinaru, R. The Impact of Digitalization on Business Sector Development in the Knowledge Economy. Proceedings of the International Conference on Business Excellence, Sciendo, 13(1), 2019. pp. 479-491.

[10]Mikhailov, A. M., \& Kopylova, A. A. Relationship Between the Economy Digitalization and the «Knowledge» Production Factor. Digital Age: Chances, Challenges and Future. ISCDTE 2019, 84, 2020. pp. 27-38. http://doi.org/10.1007/978-3-030-27015-5_4

[11]Bejinaru, R. Impact of Digitalization on Education in the Knowledge Economy. Management Dynamics in the Knowledge Economy, 7(3), 2019. pp. 367-380. https://doi.org/10.25019/MDKE/7.3/06

[12]Dornberger, R., Inglese, T., Korkut, S., \& Zhong, V. J. Digitalization: Yesterday, Today and Tomorrow. Business Information Systems and Technology 4.0. Studies in Systems, Decision and Control, 141. Springer, Cham, 2018. pp. 1-11. https://doi.org/10.1007/978-3319-74322-6_1
[13]Ilcus, M. A. Impact of Digitalization in Business World. Review of International Comparative Management, 19(4), 2018. pp. 350-358.

https://doi.org/10.24818/RMCI.2018.4.350

[14]Youssef, A. B., Boubaker, S., Dedaj, B., \& Carabregu-Vokshi, M. Digitalization of the economy and entrepreneurship intention. Technological Forecasting \& Social Change, 164. 2020.

https://doi.org/10.1016/j.techfore.2020.120043

[15]Shkarlet, S., Dubyna, M., Shtyrkhun, K., \& Verbivska, L. Transformation of the Paradigm of the Economic Entities Development in Digital Economy. WSEAS Transactions on Environment and Development, 16, 2020. pp. 413-422.

https://doi:10.37394/232015.2020.16.41

[16]Belyaeva, Z., \& Lopatkova, Ya. The Impact of Digitalization and Sustainable Development Goals in SMEs' Strategy: A Multi-Country European Study. The Changing Role of SMEs in Global Business, Palgrave Studies in Crossdisciplinary Business Research, In Association with EuroMed Academy of Business. Palgrave Macmillan, $2020 . \quad$ pp. 15-38. https://doi.org/10.1007/978-3-030-45835-5_2

[17]Branca, T. A., Fornai, B., Colla, V., Murri, M. M., Streppa, E., \& Schröder, A. J. The Challenge of Digitalization in the Steel Sector. Metals, $10(2) . \quad 2020$. https://doi.org/10.3390/met10020288

[18]Androniceanu, A.-M., Georgescu, I., Tvaronavičienè, M., \& Androniceanu, A. Canonical Correlation Analysis and a New Composite Index on Digitalization and Labor Force in the Context of the Industrial Revolution 4.0. Sustainability, 12(17), 2020. 6812. https://doi.org/10.3390/su12176812

[19]Sidorenko, E. L., \& Khisamova, Z. I. The Readiness of Economy for Digitalization: Basic Methodological Approaches. International Scientific Conference "Digital Transformation of the Economy: Challenges, Trends, New Opportunities» ISCDTE 2019: Digital Age: Chances, Challenges and Future, 84, 2020. pp. 308-316. https://doi:10.1007/978-3-030-27015537

[20]Kotarba, M. Measuring digitalization: Key metrics. Foundations of Management, 9 (1), $2017 . \quad$ pp. 123-138. https://dx.doi.org/10.1515/fman-2017-0010

[21]Kwilinski, A., Vyshnevskyi, O., \& Dzwigol, H. (). Digitalization of the EU Economies and People at Risk of Poverty or Social Exclusion. 
Journal of Risk and Financial Management, 13(7):142. 2020. https://doi.or/10.3390/jrfm13070142

[22]The European Commission. Digital Economy and Society Index (DESI) 2017. https://digitalstrategy.ec.europa.eu/en/library/digitaleconomy-and-society-index-desi-2017

[23]The European Commission. Digital Economy and Society Index (DESI) 2020. https://digitalstrategy.ec.europa.eu/en/library/digitaleconomy-and-society-index-desi-2020

[24]IMD World Competitiveness Center. The IMD World Digital Competitiveness Ranking 2016. https://www.imd.org/researchknowledge/articles/2016-com-may/

[25]IMD World Competitiveness Center. The IMD World Digital Competitiveness Ranking 2020. https://www.imd.org/wcc/worldcompetitiveness-center-rankings/world-digitalcompetitiveness-rankings-2020/

[26]Eurostat. Digital single market - promoting $e$ commerce for individuals/ 2021. https://appsso.eurostat.ec.europa.eu/nui/show.d o?dataset $=$ isoc_bdek_smi\&lang=en

[27]Alekhina E., Parakhina V., Boris O., Innovative and Motivational Competence of Leaders and Its Transformation in the Context of Digitalization, International journal of circuits, systems and signal processing, Volume 14, 2020, pp. 589-593, https://doi.org/10.46300/9106.2020.14.75.

[28]Buryk, Z., Bashtannyk, V., Ragimov, F. Economic growth: Macroeconomic effects of Public Borrowings at the global level. Problems and Perspectives in Management, 2019, 17(3), pp. 169-183
[29]Onyshchuk, S.V., Buryk, Z.M., Knysh, P.V. Management of the economic potential of territories in the context of sustainable development: Case of Ukraine. Problems and Perspectives in Management, 2019, 17(4), pp. $13-25$

[30]Arabadzhyiev, D.Yu., Buryk, Z.M., Barshatska, H.Yu., Huba, M.I., Shashyna, M.V. Establishing interterritorial cooperation of amalgamated territorial communities as a tool to increase their capacity. International Journal of Management, 2020, 11(5), pp. 1036-1044

[31]Bashtannyk, V., Buryk, Z., Kokhan, M., Vlasenko, T., Skryl, V. Financial, economic and sustainable development of states within the conditions of industry 4.0, International Journal of Management, 2020, 11(4), pp. 406-413, IJM_11_04_040

\section{Creative Commons Attribution License 4.0 (Attribution 4.0 International, CC BY 4.0)}

This article is published under the terms of the Creative Commons Attribution License 4.0 https://creativecommons.org/licenses/by/4.0/deed.en US 